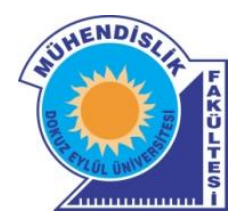

\title{
COMPARISON OF ASTAXANTHIN EXTRACTABILITY YIELDS FOR DISRUPTED HAEMATOCOCCUS CYSTS
}

\author{
(PARÇALANMIŞ HAEMATOCOCCUS KISTLERİ IÇIN ASTAKSANTIN \\ EKSTRAKT VERIMLERININ KARŞILAŞTIRILMASI)
}

\author{
Bahar ASLANBAY ${ }^{1}$, Esra İMAMOĞLU ${ }^{2}$
}

\begin{abstract}
This comprehensive study focusing on the extractability of astaxanthin from Haematococcus cysts was carried out to compare the effectiveness of the cell disruption procedures. Both single step and combined cell disruption procedures were evaluated. A physical, chemical, enzymatic or mechanical disruption process was applied prior to mechanical disruption (bead vortex homogenizer or tissue homogenizer) for the combined cell disruption procedures. In this study the best result was obtained with the consecutive mechanical disruption processes using the combined procedure of tissue homogenizer and bead vortex homogenizer, yielding $68.32 \mathrm{mg}$ Ast/g DW which was 31\% higher than that obtained with the single step bead vortex homogenizer treatment. It was concluded that the combined disruption procedures were more effective than the single step disruption procedures with respect to the extractability of astaxanthin from Haematococcus cysts.
\end{abstract}

Keywords: Astaxanthin, Cell disruption, Extraction, Haematococcus pluvialis

\section{$\ddot{O} Z$}

Bu çalışmanın ana amacı, minimum hücre içi metabolit kaybı ile maksimum ürün elde edilmesidir. Hücre parçalama teknikleri karşılaştırırlarak Haematococcus kistlerinden astaksantin ekstrakte edilebilirliği araştırılmıştır. Astaksantin eldesi üzerine fiziksel, kimyasal ve mekanik hücre parçalama işlemleri değerlendirilmiştir. Sonuç olarak, $68.32 \mathrm{mg} \mathrm{Ast/g} \mathrm{DW}$ astaksantin verimi ile kombine prosedür olan doku homojenizatörü takiben bilyalı vorteks homojenizatör uygulamasında en iyi verime ulaşılmıştır. Bu çalışmada kombine hücre parçalama işleminde tek basamaklı hücre parçalama işlemine göre daha başarılı olunmuştur.

Anahtar Kelimeler: Astaksantin, Hücre parçalama, Ekstraksiyon, Haematococcus pluvialis

\footnotetext{
1 Ege University, Faculty of Engineering, Department of Bioengineering, 35100 Bornova/Izmir/Türkiye, baharaslanbay@gmail.com

2 Ege University, Faculty of Engineering, Department of Bioengineering, 35100 Bornova/Izmir/Türkiye,, esraimamoglu@yahoo.com (corresponding author)
} 


\section{INTRODUCTION}

Astaxanthin is a valuable carotenoid pigment with applications in the nutraceutical, cosmetic, food and feed industries [1]. Astaxanthin sells for approximately $\$ 2500 \mathrm{~kg}^{-1}$ and the annual worldwide aquaculture market estimated at $\$ 200$ million. Although over $95 \%$ of this market consumes synthetically derived astaxanthin, consumer demand for natural products over the synthetic pigments provides an opportunity for the production of natural astaxanthin by Haemetococcus [2]. Haematococcus pluvialis can accumulate astaxanthin in cytoplasmic lipid vesicles, up to $8 \%$ of its dry weight in the form of $3 S, 3$ ' $S$ enantiomers, as a mixture of mono and di-esters [3].

Under optimal conditions the cells are spherical to ellipsoid and are enclosed by a cell wall, which is separated from the protoplast by a region filled with a watery jelly and traversed by cytoplasmic threads [4, 5]. There are a lot of known factors that affect the astaxanthin accumulation in $H$. pluvialis; such as nutrient limitation or supplement [6], oxygen stress [7] and high light intensity [8]. Under stress conditions, the transformation of the vegetative cells into the aplanospore is accompanied by several morphological features. The cell wall becomes considerably thicker, immobilizing the flagellae which are eventually shed [5].

Haematococcus cysts have to be broken in order to recover astaxanthin. Cell disruption is one of the important steps in the downstream processing of intracellular products from microorganisms [9, 10]. There are several methods such as homogenization [11, 12], sonication [13] and chemical extraction [14] which have been used to release intracellular components. The cell disruption techniques have an important effect on the yields and quality of the intracellular compounds and the scale of operation restrict the type of applications. Intracellular product recovery is still accomplished mainly by mechanical methods, such as high-pressure homogenization and bead mill disintegration which are used at industrial scale [15].

The main goal of this study was to obtain the maximum cell disruption with minimum loss of intracellular metabolites. The extractability of astaxanthin from Haematococcus cysts was compared using different cell disruption procedures in the single stage and the combined processes. A physical, chemical or enzymatic disruption process was applied prior to mechanical disruption (bead vortex homogenizer or tissue homogenizer) for the combined cell disruption procedures. Furthermore, the optimum disruption parameters including disruption time and rotation speed were determined for the mechanical disruption processes.

\section{MATERIALS AND METHODS}

\subsection{Preparation of Algal Biomass}

Haematococcus pluvialis Flotow EGE MACC-35 was obtained from the Culture Collection of Microalgae at the University of Ege, Izmir, Turkey. Stock culture of H. pluvialis was grown photoautotrophically in BG11 medium [16] at $25{ }^{\circ} \mathrm{C}$ under continuous illumination $\left(100 \mu \mathrm{mol}\right.$ photons $\left.\mathrm{m}^{-2} \mathrm{~s}^{-1}\right)$ in $15-\mathrm{L}$ vertical panel photobioreactor $(60 \mathrm{~cm} \mathrm{~L} \mathrm{x} 8$ $\mathrm{cm} \mathrm{W}$ x $55 \mathrm{~cm} \mathrm{H}$, thickness of glass: $1 \mathrm{~cm}$ ). The gas spargers were placed from both opposite corners of the reactor to supply air- $\mathrm{CO}_{2}$ gas mixture $\left(3 \% \mathrm{CO}_{2} / \mathrm{air} \mathrm{v} / \mathrm{v}\right)$ of $1 \mathrm{vvm}$ to the culture. The diameter of the single nozzle sparger was $0.5 \mathrm{~cm}$. The cells from the stock culture were harvested and concentrated by centrifugation at 2,000 x g for $5 \mathrm{~min}$ and the supernatant was removed. The sedimented cells were transferred, incubated aseptically in a $70 \mathrm{~L}$ panel 
photobioreactor ( $108 \mathrm{~cm} \mathrm{~L} \mathrm{x} 8 \mathrm{~cm} \mathrm{~W}$ x $126 \mathrm{~cm} \mathrm{H}$, thickness of glass: $1.5 \mathrm{~cm})$ containing $50 \mathrm{~L}$ of N:P:K 20:20:20 fertilizer [17] under the light intensity of $450 \mu \mathrm{mol}$ photons $\mathrm{m}^{-2} \mathrm{~s}^{-1}$, at 25 ${ }^{\circ} \mathrm{C}$ for 14 days of growth period. Air was supplied to the culture at a flow rate of $50 \mathrm{~L} \mathrm{~min}^{-1}$ (1.4 vvm). To induce astaxanthin accumulation, 14-day old culture (approximately $2 \times 10^{6}$ cells $\mathrm{ml}^{-1}$ ) was incubated in a $70 \mathrm{~L}$ panel photobioreactor containing $50 \mathrm{~L}$ of tap water at 1400 $\mu \mathrm{mol}$ photons $\mathrm{m}^{-2} \mathrm{~s}^{-1}$ for 14 days of induction period. The temperature was maintained at $29 \pm 2$ ${ }^{\circ} \mathrm{C}$ due to the heat dissipation from the fluorescent lamps, and was controlled with digital thermocouple inside the reactor.

Following the induction period, the encysted cell biomass was harvested by centrifugation at $2,000 \mathrm{x} \mathrm{g}$, for $5 \mathrm{~min}$, the pellet was frozen at $-20{ }^{\circ} \mathrm{C}$ and then lyophilized. The resulting freeze-dried biomass was used as raw material for the cell disruption process.

\subsection{Disruption of Microalgal Biomass}

\subsubsection{Tissue homogenizer}

$10 \mathrm{mg}$ freeze-dried biomass was placed in a $20 \mathrm{ml}$ tube containing $5 \mathrm{~mL}$ acetone and then homogenized with a tissue homogenizer (Yellow line DI25, IKA -Works, Germany) at different motor speeds. Three rotation speeds: $8000 \mathrm{rpm}, 13500 \mathrm{rpm}$, and $20500 \mathrm{rpm}$ were tested at two different disruption time: 1 and $2 \mathrm{~min}$, resulting in a total of 6 different conditions to maximize the extractability of astaxanthin from Haematococcus cysts.

\subsubsection{Autoclave treatment}

$10 \mathrm{mg}$ freeze-dried biomass was autoclaved at $121^{\circ} \mathrm{C}$ for $30 \mathrm{~min}$ under the pressure of 1.5 atm.

\subsubsection{Bead vortex homogenizer}

The bead mill was simulated using a bead vortex homogenizer for small scale studies. 10 $\mathrm{mg}$ freeze-dried biomass was placed in a $20 \mathrm{ml}$ tube containing $5 \mathrm{ml}$ acetone and charged with $50 \%(\mathrm{w} / \mathrm{v})$ of glass beads $(1 \mathrm{~mm}$ diameter). The suspension was agitated for different periods (1 and 2 min) with vortex homogenizer (Heidolph Reax Top) at different rotation speeds (825 and $1650 \mathrm{rpm}$ ), and then separated from glass beads.

\subsubsection{Sonication}

$10 \mathrm{mg}$ freeze-dried biomass was placed in a $20 \mathrm{ml}$ tube containing $5 \mathrm{ml}$ acetone and was sonicated using a sonicator (Bandelin Electronic UW 2070, Berlin, Germany) for $10 \mathrm{~min}$ at $0.8 \mathrm{sec}$ intervals. The dismembrator had a maximum power output of $180 \mathrm{~W}$ and was operated at a constant frequency of $20 \mathrm{kHz}$. The horn was placed at the center of the tube. Sonication was carried out in an ice-water bath to avoid the increase of temperature that could affect the cell viability and the product quality.

\subsubsection{Alkaline hydrolysis}

$10 \mathrm{mg}$ freeze-dried biomass was treated in $0.1 \mathrm{M} \mathrm{NaOH}$ for $30 \mathrm{~min}$. The supernatant was removed by centrifugation $(2,000 \mathrm{x} \mathrm{g}, 5 \mathrm{~min})$.

\subsubsection{Enzyme treatment}

The mixtures of $10 \mathrm{mg}$ freeze-dried biomass, $10 \mathrm{mg}$ cellulase (Sigma Chemical Co., St Louis, MO, USA) and $10 \mathrm{mg}$ distilled water were prepared to obtain enzyme reaction mixtures and were incubated for $24 \mathrm{~h}$ at $37{ }^{\circ} \mathrm{C}$. Enzyme-treated biomass was harvested by centrifugation at $2,000 \mathrm{x} \mathrm{g}$, for $5 \mathrm{~min}$ [18]. 


\subsection{Analytical Procedure}

The cell disruption performance was determined using a modified method from MendesPinto et al. [19]. $10 \mathrm{mg}$ disrupted cells were mixed with $5 \mathrm{ml}$ acetone (Carlo Erba, 99\%). The suspension was agitated for 3-4 min in a vortex and was left for 16 hours at the room temperature. The cell debris was removed by centrifugation prior to analysis. The absorbance of the combined extracts was measured at $480 \mathrm{~nm}$. Astaxanthin concentration was determined using a calibration curve obtained with pure astaxanthin (Acros Co., New Jersey, USA) as a standard $\left(\mathrm{E}_{1 \mathrm{~cm}}^{1 \%} 2500\right.$ in acetone). All data represent the means of three independent experiments.

\section{RESULTS}

The effects of 6 different cell disruption procedures on the extractability of astaxanthin from Haematococcus cysts were investigated. Both single step and combined cell disruption procedures were evaluated. A physical, chemical, enzymatic or mechanical disruption process was applied prior to mechanical disruption (bead vortex homogenizer or tissue homogenizer) for the combined cell disruption procedures. Furthermore, the optimum disruption parameters including disruption time and rotation speed were determined for the mechanical disruption processes.

\subsection{Determination of Optimum Disruption Parameters for the Mechanical Disruption Processes}

As shown in Figure 1A, when the cells were treated in the tissue homogenizer at 13500 $\mathrm{rpm}$ for $2 \mathrm{~min}$, the release of astaxanthin was $32.15 \mathrm{mg}$ Ast/g DW which was 1.1 fold higher than for $1 \mathrm{~min}$ at the same rotation speed. The release of astaxanthin was significantly lower (21.74 mg Ast/g DW) at $8000 \mathrm{rpm}$ for $1 \mathrm{~min}$. The best result (39.44 mg Ast/g DW) was obtained at the rotation speed of $20500 \mathrm{rpm}$ for $2 \mathrm{~min}$ in the process of tissue homogenizer. In Figure 1B, the lowest astaxanthin recovery, $21.22 \mathrm{mg} \mathrm{Ast} / \mathrm{g} \mathrm{DW}$, was obtained at $825 \mathrm{rpm}$ for $1 \mathrm{~min}$ whereas the release of astaxanthin was $38.64 \mathrm{mg}$ Ast/g DW at $1650 \mathrm{rpm}$ for the same disruption time in the process of bead vortex homogenizer.
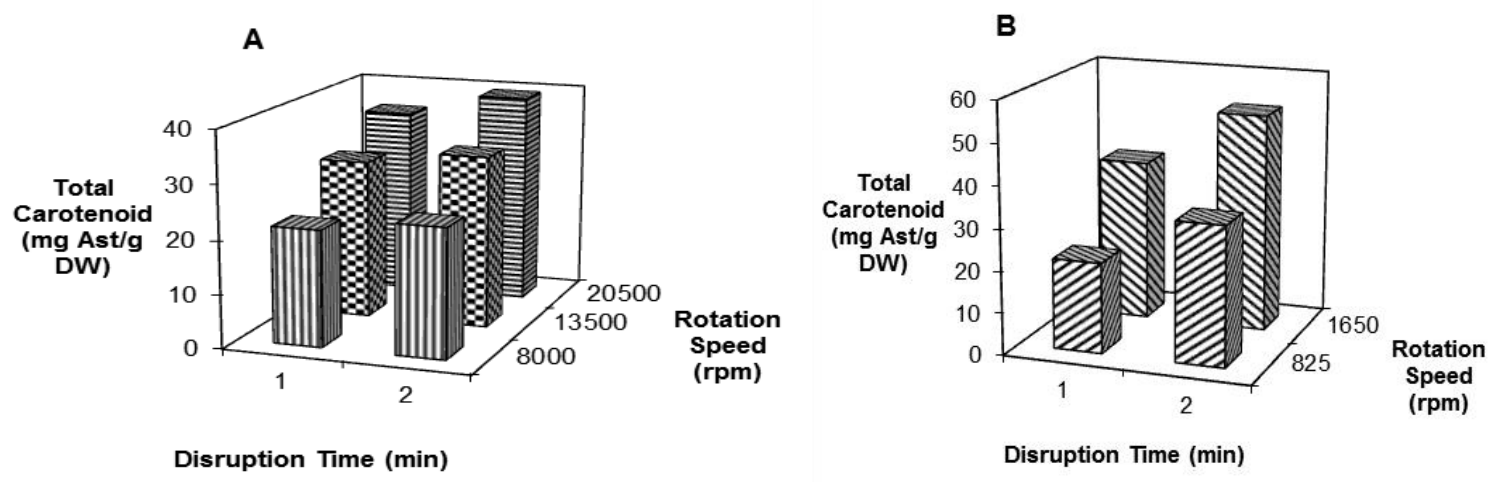

Figure 1. Determination of optimum disruption parameters for the mechanical disruption processes:

A. Tissue homogenizer, B. Bead vortex homogenizer 


\subsection{Single Stage Cell Disruption Procedures}

When single step cell disruption procedures were applied, the best recoveries of astaxanthin were found in bead vortex homogenizer at $1650 \mathrm{rpm}$ for $2 \mathrm{~min}$ and tissue homogenizer at $20500 \mathrm{rpm}$ for 2 min with the values of 52.36 and $39.44 \mathrm{mg}$ Ast/g DW, respectively (Figure 2). The release of astaxanthin was $29.29 \mathrm{mg}$ Ast/g DW with the alkaline hydrolysis procedure employed. Similar yields were observed for cells that were exposed to sonication (27.84 mg Ast/g DW). The astaxanthin obtained by autoclave treatment was 1.02 times higher than that obtained by enzyme treatment.

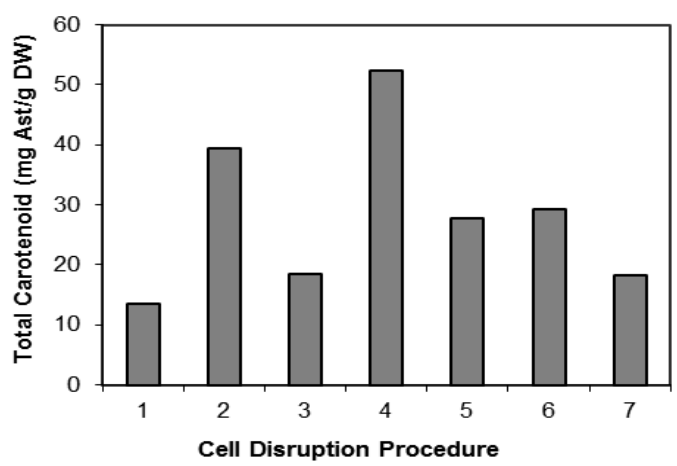

Figure 2. Comparison of the single step cell disruption procedures for the release of astaxanthin from Haematococcus cysts: 1. Control; 2. Tissue Homogenizer; 3. Autoclave treatment; 4. Bead vortex homogenizer; 5. Sonication; 6. Alkaline hydrolysis; 7. Enzyme treatment

\subsection{Combined Cell Disruption Procedures}

The intact cyst cells were treated with the combination of two different disruption processes in order to increase the efficiency of astaxanthin extractability from Haematococcus cysts (Table 1). A physical, chemical, enzymatic or mechanical disruption process was applied prior to mechanical disruption (bead vortex homogenizer or tissue homogenizer). When the cells were treated in the tissue homogenizer following bead vortex homogenizer treatment, the release of astaxanthin was $68.32 \mathrm{mg}$ Ast/g DW which was 1.3 fold higher than the single step bead vortex homogenizer treatment. The release of astaxanthin was $57.42 \mathrm{mg}$ Ast/g DW with the combination of sonication and tissue homogenizer. The astaxanthin recovery increased by $76 \%$ with the combination of alkaline hydrolysis and bead vortex homogenizer in comparison with the single step alkaline hydrolysis procedure. The release of astaxanthin (43.50 mg Ast/g DW) obtained with the combined procedure of enzyme treatment and bead vortex homogenizer was $21 \%$ higher than that obtained with the combined procedure of enzyme treatment and tissue homogenizer. The lowest yield was attained with the combination procedure of autoclave treatment and tissue homogenizer $(34.22 \mathrm{mg}$ Ast/g DW).

The best result was obtained with the consecutive mechanical disruption processes using the combined procedure of tissue homogenizer and bead vortex homogenizer yielding 68.32 mg Ast/g DW which was $31 \%$ higher than that obtained with the single step bead vortex homogenizer treatment. It was concluded that the combined disruption procedures on the extractability of astaxanthin from Haematococcus cysts were more effective than the single step disruption procedures. 
Table 1. Comparison of the combined cell disruption procedures for the release of astaxanthin from Haematococcus cysts: 1. Control; 2. Tissue Homogenizer; 3. Autoclave treatment; 4. Bead vortex homogenizer; 5. Sonication; 6. Alkaline hydrolysis; 7. Enzyme treatment. (+): Applied, (-): Unapplied

\begin{tabular}{cccccccc}
\hline \multicolumn{1}{c}{ Cell disruption procedures } & \multicolumn{2}{c}{ mg Ast/g } \\
1 & 2 & 3 & 4 & 5 & 6 & 7 & DW \\
\hline- & + & + & - & - & - & - & 34.22 \\
- & + & - & + & - & - & - & 68.32 \\
- & + & - & - & + & - & - & 57.42 \\
- & + & - & - & - & + & - & 47.62 \\
- & + & - & - & - & - & + & 36.09 \\
- & - & + & + & - & - & - & 43.21 \\
- & - & - & + & + & - & - & 60.32 \\
- & - & - & + & - & + & - & 51.68 \\
- & - & - & + & - & - & + & 43.50 \\
\hline
\end{tabular}

These results are an average of 3 different determinations with a standard error of $\pm 5 \%$

\section{DISCUSSION}

Several experiments on the cell disruption procedures have been carried out by different authors. It is rather difficult to compare the results due to the differences in cultivation and disruption conditions. In some previous work, the algal cells were disrupted by using the tissue homogenizer [8], grinding with mortar and pestle [20-22], heating at $60{ }^{\circ} \mathrm{C}$ [23] and 70 ${ }^{\circ} \mathrm{C}[24,25]$, or enzymatic disruption [26, 27]. As reported by Kobayashi et al. [18], the percentage of astaxanthin extractability from Haematococcus cysts was $13 \%$ with the enzyme (cellulase) treatment while this value was $38 \%$ in the combination procedure of heat-acetone and enzyme treatment.

Haematococcus pluvialis shows low growth rates and low final cell densities under optimal growth conditions [28]. Cells grown at a higher specific growth rate are probably easier to disrupt than cells grown at a lower specific growth rate, since they direct the available energy towards reproduction rather than towards synthesis or strengthening the wall structure [29, 30].

Mechanical methods have several disadvantages, such as the absence of biological specificity, generation of high temperature in cell suspensions and high shear stress high capital investment cost, and long processing times. Chemical extraction is a possible substitute for mechanical disruption owing to its simplicity, relative speed and low cost [31, 32].

The addition of $\mathrm{NaOH}$ was necessary for the hydrolysis of astaxanthin esters, but $\mathrm{NaOH}$ could result in significant degradation of astaxanthins, especially when the reaction temperature was high. The results of Yuan and Chen [33] indicated that, although high temperature favoured the hydrolysis of astaxanthin esters, the degradation of astaxanthins was also promoted markedly at the same time. Therefore, the saponification should be carried out at a low temperature to minimize the degradation of astaxanthins during the hydrolysis of astaxanthin esters [27].

The results of this study indicate that tissue homogenizer has drawbacks, such as foaming and oxygen permeability except the above-mentioned. The reaction temperature also increases at high rotation speeds for the long disruption time due to the heat energy given off by the 
friction forces. The high temperature could lead to metabolite degradation. To overcome these problems, tissue homogenizer should be operated at the optimum rotation speed within the shortest possible time. The mechanical tissue homogenizer is applied under the effects of both the frictional forces and the shear stress whereas the thermal autoclave treatment is only achieved at the high temperature.

Disruption involving rapid agitation of microbial cell suspension with glass beads is also a powerful technique. This procedure is particularly efficient in the disruption of yeasts and filamentous fungi, which have rigid cell walls mainly constituted by polysaccharides (80$90 \%)[29,34]$. The degree of disruption increases with bead loading due to increased bead-tobead interaction; however, heating and power consumption also increase, because of this interaction [35].

Under the stress conditions Haematococcus cell is surrounded by a heavy resistant cellulose wall while astaxanthin is accumulated within oil droplets. This cellulosic structure naturally protects metabolites inside the cell. In this study, the cellulase enzyme was selected for the cell disruption process due to the cellulosic cell wall of Haematococcus cysts.

Sonication is normally carried out in bursts to reduce the heating effect and only used on a small scale. The mechanism of the cell disruption is associated with the cavitation phenomena, i.e. shear stress developed by viscous dissipative eddies arising from shock waves produced by imploding cavitation bubbles. Shear forces creating eddies larger than the cells are more likely to move the cells rather than disrupt them, whereas eddies smaller than the cells are capable of generating disruptive shear stresses. Thus, larger cells will experience more disruptive eddies than smaller cells. Increasing the power (intensity) will shift the size distribution towards smaller eddies, which in turn, will increase the number of disruptive eddies acting on the cells resulting in greater disruption [36]. It is also worth noting that the sonication process is more efficient for the microorganisms enclosed by less rigid cell wall. No experimental studies had been encountered concerning the sonication process on the extractability of astaxanthin from Haematococcus cysts in the scientific literature.

The ideal process involves the minimum number of downstream steps with high recovery and minimum effort for the adequate quality of the desired product. Increasing the number of process steps will normally decrease the productivity as well as increase in cost for downstream processing. The cell disruption processes have been receiving special attention in recent years for the combination of process steps to increase yield, to reduce of process time and to cut down in capital expenditure.

The effectiveness of the various disruption methods differs for different microbial species, depending on the properties of valuable intracellular products. It is also interesting to note that the grade of cell sticking on the chamber wall was significantly higher for the recovery of astaxanthin from Haematococcus cysts. Transferring the sample from one apparatus to another was a big problem due to the remaining cell debris for the combined disruption process. Therefore, a physical, chemical, enzymatic or mechanical disruption process was applied prior to mechanical disruption in order to minimize the loss of intracellular metabolites.

\section{CONCLUSION}


In this work, the best result was obtained with the consecutive mechanical disruption processes using the combined procedure of tissue homogenizer and bead vortex homogenizer yielding $68.32 \mathrm{mg}$ Ast/g DW which was $31 \%$ higher than that obtained with the single step bead vortex homogenizer treatment. It was concluded that the combined disruption procedures on the extractability of astaxanthin from Haematococcus cysts were more effective than the single step disruption procedures. The main point is whether the increasing of $31 \%$ yield will meet the expectations concerning the capital expenditure for the combined disruption process, or not.

\section{REFERENCES}

[1] Guerin M, Huntley ME, Olaizola M. Haematococcus Astaxanthin: Applications for Human Health and Nutrition, Trends Biotechnology, Vol. 21, 2003, pp.210-216.

[2] Richmond A. Handbook of Microalgal Culture: Biotechnology and Applied Phycology, Iowa: Iowa State Press, 2004.

[3] Harker M, Tsavalos AJ, Young AJ. Autotrophic Growth and Carotenoid Production of Haematococcus Pluvialis in a 30 Liter Air-Lift Photobioreactor, Journal of Fermentation and Bioengineerig, Vol. 82, 1996, pp.113-118.

[4] Santos MF, Mesquita JF. Ultrastructural Study of Haematococcus Lacustris (Girod) Rostafinski (Volvocales). I. Some Aspects of Carotenogenesis, Cytologia, Vol. 49, 1994, pp.215-228.

[5] Margalith P. Production of Ketocarotenoids by Microalgae, Applied Microbiology and Biotechnology, Vol. 51, 1999, pp.431-438.

[6] Fabregas J, Dominguez A, Maseda A, Otero A. Interactions between Irradiance and Nutrient Availability during astaxanthin Accumulation and Degradation in Haematococcus Pluvialis, Applied Microbiology and Biotechnology, Vol. 61, 2003, pp.545-551.

[7] Kobayashi M, Kakizono T, Nishio N, Nagai S. Effects of Light Intensity, Light Quality, and Illumination Cycle on Astaxanthin Formation in a Green Alga Haematococcus Pluvialis, Journal of Fermentation and Bioengineerig, Vol. 74, 1992, pp.61-63.

[8] Harker M, Tsavalos AJ, Young AJ. Factors Responsible for Astaxanthin Formation in the Chlorophyte Haematococcus Pluvialis, Bioresource Technology, Vol. 55, 1996, pp.207-214.

[9] Lovitt RW, Jones M, Collins SE, Coss GM, Yau CP, Attouch C. Disruption of Baker's Yeast Using a Disrupter of Simple and Novel Geometry, Process Biochemistry, Vol. 36, 2000, pp.415-421.

[10] Balasundaram B, Pandit AB. Selective Release of Invertase by Hydrodynamic Cavitation, Biochemical Engineering Journal, Vol. 8, 2001, pp.251-256.

[11] Dickson RC, Dickson LR, Markin JS. Purification and Properties of an Inducible $\beta$ Galactosidase Isolated from the Yeast Kluyveromyces Lactis, Journal of Bacteriology, Vol. 137, 1979, pp.51-61.

[12] Brady D, Marchant R, McHale L, McHale AP. Isolation and Partial Characterization of $\beta$-Galactosidase Activity Produced by a Thermotolerant Strain of Kluyveromyces Marxianus during Growth on Lactose-Containing Media, Enzyme and Microbial Technology, Vol. 17, 1995, pp.696-699.

[13] Lind DL, Daniel RM, Cowan DA, Morgan HW. A Thermostable B-Galactosidase from a Strain of the Anaerobic Thermophile Thermoanaerobacter, Enzyme and Microbial Technology, Vol. 11, 1989, pp.180-186. 
[14] Stred'anský M, Tomáska M, Sturdík E, Kremnický L. Optimization of $\beta$-Galactosidase Extraction from Kluyveromyces Marxianus, Enzyme and Microbial Technology, Vol. 15, 1993, pp.1063-1065.

[15] Belo I, Santos JAL, Cabral JMS, Mota M. Optimization Study of Escherichia Coli TB1 Cell Disruption for Cytochrome $b_{5}$ Recovery in a Small-Scale Bead Mill, Biotechnology Progress, Vol. 12, 1996, pp.201-204.

[16] Rippka R, Deruelles JB, Herdman M, Stanier RY. Assignments Strain History and Properties of Pure Cultures of Cyanobacteria, Journal of General Microbiology, Vol. 111, 1979, pp.1-61.

[17] Dalay M, Imamoglu E, Demirel Z. Agricultural Fertilizers as Economical Alternative for Cultivation of Haematococcus Pluvialis, J Microbiology and Biotechnology, Vol. 17, 2007, pp.393-397.

[18] Kobayashi M, Kurimura Y, Sakamoto Y, Tsuji Y, Selective Extraction of Astaxanthin and chlorophyll from the Green Alga Haematococcus Pluvialis, Biotechnology Technology, Vol. 11, 1997, pp.657-660.

[19] Mendes-Pinto M, Raposo MFJ, Bowen J, Young AJ, Morais R. Evaluation of Different Cell Disruption Processes on Encysted Cells of Haematococcus Pluvialis: Effects on Astaxanthin Recovery and Implications for Bio-availability, Joural of Applied Phycology, Vol. 13, 2001, pp.19-24.

[20] Choubert G, Heinrich O. Carotenoid Pigments of the Green Alga Haematococcus Pluvialis: Assay on Rainbow Trout, Oncorhynchus Mykiss, Pigmentation in Comparison with Synthetic Astaxanthin and Canthaxanthin, Aquaculture, Vol. 112, 1993, pp.217-226.

[21] Hagen C, Braune W, Birckner E, Nuske J. Functional Aspects of Secondary Carotenoids in Haematococcus Lacustris (Girod) Rostafinski (Volvocales), New Phytology, Vol. 125, 1993, pp.625-633.

[22] Kobayashi M, Kakizono T, Nagai S. Enhanced Carotenoid Biosynthesis by Oxidative Stress in Acetate-Induced Cyst Cells of a Green Unicellular Alga, Haematococcus pluvialis, Applied Environmental Microbiology, Vol. 59, 1993, pp.867-873.

[23] Xylander M, Braune W. Influence of Nickel on the Green Alga Haematococcus Lacustris Rostafinski in Phases of its Life Cycle, Journal of Plant Physiology, Vol. 144, 1994, pp.86-93.

[24] Bar E, Rise M, Vishkautsan M, Arad S. Pigment and Structural Changes in Chlorella Zofingiensis upon Light and Nitrogen Stress, Journal of Plant Physiology, Vol. 146, 1995, pp.527-534.

[25] Rise M, Cohen E, Vishkautsan M, Cojocarum M, Gottlieb HE, Arad S. Accumulation of Secondary Carotenoids in Chlorella Zofingiensis, Journal of Plant Physiology, Vol. 144, 1994, pp.287-292.

[26] Grung M, D'Souza FML, Borowitzka M, Liaaen-Jensen S. Algal Carotenoids 51. Secondary Carotenoids 2. Haematococcus Pluvialis Aplanospores as a Source of (3S, 30S)-Astaxanthin Esters, Journal of Applied Phycology, Vol. 4, 1992, pp.165-171.

[27] Yuan JP, Chen F. Purification of Trans-Astaxanthin from a High-Yielding Astaxanthin Ester-Producing Strain of the Microalga Haematococcus Pluvialis, Food Chemistry, Vol. 68, 2000, pp.443-448.

[28] Fàbregas J, Domìnguez A, Regueiro M. Optimization of Culture Medium for the Continuous Cultivation of the Microalga Haeamatococcus Pluvialis, Applied Microbiology and Biotechnology, Vol. 53, 2000, pp.530-535.

[29] Keshavarz E, Hoare M. Dunnill P. Biochemical Engineering Aspects of Cell Disruption, Chichester: Chichester Horwood press, 1987. 
[30] Becerra M, Rodríguez-Belmonte E, Cerdán MA, Siso MIG. Extraction of Intracellular Proteins from Kluyveromyces Lactis, Food Technology and Biotechnology, Vol. 39, 2001, pp.135-139.

[31] Choe WS, Middelberg APJ. Direct Chemical Extraction of a Recombinant Viral Coat Protein from Escherichia Coli at High Cell Density, Biotechnology and Bioengineering, Vol.75, 2001, pp.451-455.

[32] Park PK, Kim EY, Chu KH. Chemical Disruption of Yeast Cells for the Isolation of Carotenoid Pigments, Seperation and Purification Technology, Vol. 53, 2007, pp.148152.

[33] Yuan JP, Chen F. Hydrolysis Kinetics of Astaxanthin Esters and Stability of Astaxanthin of Haematococcus Pluvialis during Saponification, Journal of Agricultural and Food Chemistry, Vol. 47, 1999, pp.31-35.

[34] Gurpilhares DB, Francislene AH, Pessoa AJ, In^es CR. Optimization of Glucose-6Phosphate Dehydrogenase Releasing from Candida Guilliermondii by Disruption with Glass Beads, Enzyme and Microbial Technology, Vol. 39, 2006, pp.591-595.

[35] Geciova J, Bury D, Jelen P. Methods for Disruption of Microbial Cells for Potential Use in the Dairy Industry, International Dairy Journal, Vol. 12, 2002, pp.541-553.

[36] Doulah M.S. Mechanism of Disintegration of Biological Cells in Ultrasonic Cavitation, Biotechnology and Bioengineering, Vol. 19, 1977, pp.649-660.

\section{ÖZGEÇMIȘ/CV}

Bahar ASLANBAY; M.Sc. Student (yüksek lisans öğrencisi)

She got her bachelors' degree in Bioengineering Department at Ege University, Izmir/Turkey in 2015 and in the same year, she has started her master programme in the same department. Her research interests include microalgal biotechnology, bioprocess engineering.

Lisans derecesini 2015'de Ege Üniversitesi Biyomühendislik Bölümü'nden aldı ve aynı yıl Biyomühendislik Bölümünde yüksek lisansa başladı. Araştırma Alanları: Mikroalgal biyoteknoloji, biyoproses mühendisliği.

Esra IMAMOGLU; Assistant Prof. (Yrd. Doç. Dr.)

She got the PhD degree in Bioengineering at Ege University in 2011. She is still an academic member of Bioengineering Department at Ege University. Her research interests include microalgal biotechnology, biofuels, bioprocess engineering. She has been involved in EU activities (EU FP6-FP7 and COST projects) as a researcher.

Doktora derecesini 2011 yılında Ege Üniversitesi Biyomühendislik Bölümünden aldı. Hala Ege Üniversitesi Biyomühendislik Bölümü'nde öğretim üyesi olarak görev yapmaktadır. Araştırma Alanları: Mikroalgal biyoteknoloji, biyoyakıtlar, biyoproses mühendisliği. Araştırmacı olarak Avrupa Birliği FP6, FP7 ve Cost Aksiyonlarında görev almaktadır. 